\title{
Happiness among poor women victims of intimate partner violence in Nicaragua.
}

José Juan Vázquez

Instituto Universitaro de Investigación en Estudios Latinoamericanos (IELAT)

Universidad de Alcalá

\section{Sonia Panadero}

Universidad Complutense de Madrid

\section{Esther Rivas}

Universidad de Alcalá

\begin{abstract}
The paper analyzes various aspects of overall happiness expressed by 136 women in poverty who are victims of intimate partner violence (IPV) in Nicaragua, a country with low levels of development. The information was gathered using a structured interview. Results obtained show that despite the hardships they face, half of the women in poverty who are victims of IPV say they are happy, and the vast majority are optimistic about their future. The main sources of happiness among the interviewees are in areas outside their economic life, and are mainly associated with social relations.
\end{abstract}

Key words: happiness, poverty, intimate partner violence, Nicaragua, developing country. 


\section{Happiness among poor women victims of intimate partner violence in Nicaragua.}

\section{Introduction}

In recent years the study of issues related to happiness has been a highly productive area of work, and a topic of growing interest internationally (Lyubomirsky, King \& Diener, 2005). However, little research has focused on groups in situations of social difficulty, especially in countries with low levels of development (Vázquez, 2013). This is despite the fact that as Diener (1984) points out, the influence of external factors such as the lack of sufficient resources to meet basic needs (Diener \& Biswas-Diener, 2002; Diener, Ng, Harter \& Arora, 2010), may be more relevant for personal happiness that an individual's various dispositional factors.

Various studies highlight the existence of a positive relationship between happiness and level of income (Andrews, 1986; Diener, Sandvik, Seidlitz \& Diener, 1993; Oswald, 1997), and note that the individual's personal financial situation may play an important role in accounting for happiness (Rojas, 2011). Poverty has often been considered a situation in which the degree of wellbeing is very low (Rojas, 2006), and extreme poverty is thought to have a very negative effect on happiness (Graham, 2005). The normal perception is therefore that a very poor person can hardly ever be happy and in cases where this occurs, their happiness is attributed to the very low level of their future expectations, or their ability to adapt to their apparently unfortunate situation (Rojas, 2011).

However, as Rojas (2011) points out, individuals are more than mere consumers, and there are other things in their lives besides money. Indeed, the relationship between income levels and satisfaction in other relevant areas of life is practically non-existent, and as such the income level alone predicts practically nothing about satisfaction in several areas that are important to individuals (Rojas, 2011). It is therefore common to find happy people with very low incomes, which could explain why these individuals obtain a great deal of satisfaction in other areas of their lives (Rojas, 2008).

Social relationships and stable ties with family, friends, partners and community are to a large extent predictors of subjective well-being and overall happiness (Diener \& Seligman, 2002; Gustavson et al., 2012), but Brannan et al. (2012) noted that despite the growing number of crosscultural studies focusing on well-being, little is known about social support outside the western civilization. Individuals mention feelings of happiness when they meet others (Pavot, Diener \& Fujita, 1990). Furthermore, people who say they are very happy have stronger relationships with family, friends and couples (Diener \& Seligman, 2002). The consistency of the data leads to the conclusion that social relationships are necessary for happiness (Diener \& Oishi, 2005; Diener \& Seligman, 2002). Caunt, Franklin, Brodaty and Brodaty (2012) note that social relationships are a very important factor in people's well-being, and especially in relationships with family and friends, but also relationships in general. In this regard, a lack of social relations, or social relations of poor quality, has a significant negative impact on happiness (Campbell, 1981; Dolan, Peasgood \& White, 2008).

The different circumstances surrounding people, in terms of secure and stable elements in their life, also appear to have a significant effect on their subjective well-being and overall 
happiness, possibly because of adaptation (Diener, Lucas \& Scollon, 2006; Lyubomirsky, 2011; Lyubomirsky et al. 2005). Some of the circumstances that most consistently predict high levels of overall happiness are being married (Diener, Gohm, Suh \& Oishi, 2000; Lee, Seccombe \& Shehan, 1991; Myers, 2000; Stack \& Eshelmen, 1998,), and being sufficiently wealthy to meet basic needs (Diener \& Biswas-Diener, 2002; Diener, Diener \& Diener, 1995; Diener et al. 1993, 2010). Caunt et al. (2012) note that while having sufficient wealth is well represented among the recipes for happiness, relationships within a couple, including a "happy marriage", were mentioned as sources of happiness with a moderate frequency.

Meanwhile, optimism is considered a personality trait that can predict high levels of subjective well-being and overall happiness according to various authors (Carver \& Gains, 1987; Fontaine \& Jones, 1997; Scheier \& Carver, 1992). Various authors believe that optimism is an inherited personality factor with a stable effect on daily fluctuations in attitudes, emotions and behaviours (Diener \& Lucas, 1999; Weis, Bates \& Luciano, 2008).

Nicaragua, with an estimated population of 5.5 million inhabitants, is one of the countries in Latin America with the lowest levels of development (UNDP, 2011). 15.8\% of Nicaragua's population lives on less than 1.25 dollars a day, and $45.8 \%$ live below the national poverty line (UNDP, 2010). León, the country's second most important city after the capital, has a population of approximately 185,000 inhabitants. Estimates suggest that more than half the city's inhabitants live below the poverty line, and that there are major pockets of population living in extreme poverty (Vazquez, Panadero \& Martín, 2012, Vázquez, 2013). This study was prompted by the lack of research on well-being and overall happiness among women in poverty who are victims of IPV in the poorest countries, who are in addition heavily stigmatized and subject to very difficult life circumstances.

\section{Sample.}

\section{Method}

The participants in the research were 136 women living in poverty, who were victims of intimate partner violence (IPV) in León (Nicaragua), a group that is difficult to access and which lives under a particularly severe range of stressful situations. Those meeting the criterion for inclusion in the sample were women living in poverty who had suffered from violence inflicted by their spouse or partner. Access to the interviewees was possible thanks to the support provided by various associations and institutions working with women living in poverty in León, including the Commissariat for Women of the Nicaraguan National Police.

The interviewees, whose mean age was 31.67 years old $(\mathrm{SD}=8.921)$ had a mean of 2.23 children ( $\mathrm{SD}=1.655)$. On average, they began living with the partner who subjected them to the assaults at a mean age of 19.91 years old $(\mathrm{SD}=4.929)$ and had cohabited or lived with their assailant for a mean of 9.16 years $(\mathrm{SD}=6789)$. Other characteristics of the women in poverty who are victims of intimate partner interviewed are listed in Table 1. 
Table 1. Characteristics of women in poverty who are victims of intimate partner violence in León (Nicaragua)

\begin{tabular}{|c|c|c|}
\hline .Characteristics & $\mathbf{n}$ & Percentage \\
\hline \multicolumn{3}{|l|}{ Marital status } \\
\hline Single & 27 & $28.4 \%$ \\
\hline Married & 26 & $27.4 \%$ \\
\hline Stable de facto union & 21 & $22.1 \%$ \\
\hline Separated & 17 & $17.9 \%$ \\
\hline Divorced & 4 & $4.2 \%$ \\
\hline \multicolumn{3}{|l|}{ Level of education } \\
\hline No education & 3 & $3.5 \%$ \\
\hline Basic-primary education & 62 & $65.3 \%$ \\
\hline Intermediate-secondary education & 14 & $14.8 \%$ \\
\hline Higher technical & 7 & $7.4 \%$ \\
\hline Incomplete university & 9 & $9.5 \%$ \\
\hline Complete university & 5 & $5.3 \%$ \\
\hline \multicolumn{3}{|l|}{ Employment status } \\
\hline Unemployed & 14 & $14.7 \%$ \\
\hline Housewife & 23 & $24.2 \%$ \\
\hline Casual worker & 24 & $25.3 \%$ \\
\hline Dependent stable worker & 21 & $22.1 \%$ \\
\hline Independent stable worker & 13 & $13.7 \%$ \\
\hline Entrepreneur/microentrepreneur & 1 & $1.1 \%$ \\
\hline Lives with her partner (assailant) & 33 & $34.7 \%$ \\
\hline \multicolumn{3}{|l|}{ Main breadwinner in the home } \\
\hline Interviewee & 26 & $28.3 \%$ \\
\hline Spouse or partner & 33 & $35.9 \%$ \\
\hline Father & 15 & $16.3 \%$ \\
\hline Mother & 7 & $7.6 \%$ \\
\hline Relatives & 11 & $11.9 \%$ \\
\hline \multicolumn{3}{|c|}{ Approximate income level of the household } \\
\hline Less than 25 dollars a week & 17 & $20.5 \%$ \\
\hline 25 to 50 dollars a week & 28 & $33.7 \%$ \\
\hline 50 to 100 dollars a week & 20 & $24.1 \%$ \\
\hline Over 100 dollars a week & 18 & $21.7 \%$ \\
\hline \multicolumn{3}{|l|}{ Interviewee's approximate income level } \\
\hline No income of her own & 33 & $35.1 \%$ \\
\hline Less than 25 dollars a week & 30 & $31.9 \%$ \\
\hline 25 to 50 dollars a week & 19 & $20.2 \%$ \\
\hline 50 to 100 dollars a week & 10 & $10.6 \%$ \\
\hline Over 100 dollars a week & 2 & $2.1 \%$ \\
\hline
\end{tabular}

As can be seen in Table 1, almost half (49.5\%) of the women in poverty who are victims of IPV who were interviewed lived in cohabiting couples, while one in five $(22.1 \%)$ were separated or divorced. The majority of the interviewees had no education higher than primary level, and a large 
percentage had no income of their own (as they were unemployed or housewives), although most of them did some work $(62.2 \%)$ from which they obtained income. This exceeded 50 dollars a week for a small percentage of the interviewees. One third of the women interviewed lived with their assailant, who in these cases tended to be the main contributor to the household income.

\section{Procedure.}

After locating each woman in poverty who was a victim of intimate partner violence, the interviewer made contact, explained the objectives of the research and the treatment that the data would be subjected to, and sought informed consent for the interview. $51.6 \%$ of the women were interviewed in their own homes, $38.9 \%$ in the Commissariat for Women of the Nicaraguan National Police in León, and $9.5 \%$ at the headquarters of various associations and nongovernmental organisations which collaborated with the research.

The data was collected using a structured interview designed for that purpose, which circumvented the problems caused by some difficulties with reading and comprehension among some of the women in poverty who are victims of IPV interviewed. Due to some of the interviewees' limited ability as regards reading and comprehension, we used an instrument that combined illustrations with explanations by the interviewers, shown in Figure 1, to gather the information on overall happiness.

Figure 1. Instrument used to collect information on overall happiness among women in poverty who are victims of intimate partner violence in León (Nicaragua).

Which of the following faces best represents your overall level of happiness?

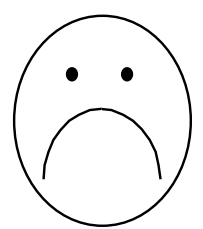

1

Very

unhappy

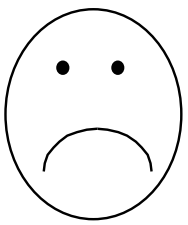

2

Quite unhappy

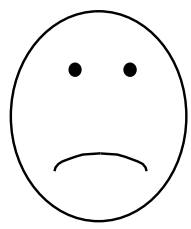

3

A little unhappy

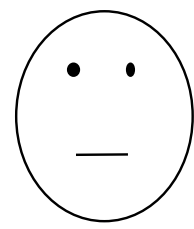

4

Not happy or unhappy

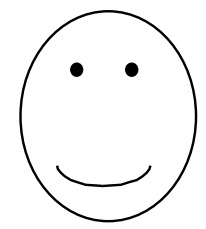

5

A little happy

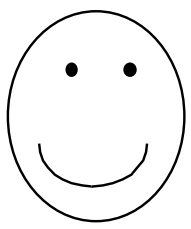

6

Quite

happy

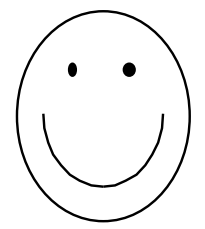

7

Very

happy

Although collecting information on overall happiness is complex, according to Schimmel (2009), people regularly think about happiness, and as pointed out by Karma and Karma (2004), they tend to have a fairly clear idea of what happiness is. While there is some disagreement on how best to measure overall happiness, authors such as Easterlin (2001) and Veenhoven (1993) emphasize that despite not being perfect, the use of subjective indicators (like the one used in this study) adequately reflect the respondents' feelings regarding their happiness in different countries and cultures.

In order to facilitate comparisons between interviewees according to their happiness, the "Overall Happiness" variable was dichotomized to distinguish between women who said they were "Unhappy" ("very unhappy", "quite unhappy" and "a little unhappy") from those who said they were "Happy" ("very happy," "quite happy" and "a little happy"). The interview included the "Scale of Perceived Social Support" (Arechabala \& Miranda, 2002), a Spanish adaptation of the MSPSS scale (Zimet, Dahlem, Zimet \& Farley, 1988), consisting of 12 items, which include information on 
individuals' perceived social support in three areas: family, friends and significant others. The instrument was answered using a Likert scale with four response options: 1="almost never", 2="sometimes", 3="often", 4="always or almost always."

The database was developed and processed using the SPSS statistical analysis and data management system (version 19.0 for Windows.) The data obtained was used to undertake descriptive analyzes that included information on women in poverty who were victims of intimate partner violence. When making comparisons, the $\chi 2$ "Chi square" statistic was used for nominal variables, and the "Student $t$ test for independent samples" was used for continuous variables.

\section{Results}

The results obtained show that more than half of women in poverty who are victims of IPV in León (Nicaragua) say that they are happy, and most had positive expectations for the future. Table 2 shows the overall level of happiness expressed by the women interviewed and their future expectations.

Table 2. Overall level of happiness and future expectations among women in poverty who are victims of intimate partner violence in León (Nicaragua)

\begin{tabular}{lrr}
\hline & $\mathbf{n}$ & $\mathbf{\%}$ \\
\hline Overall level of happiness & 9 & \\
Very happy & 32 & $23.5 \%$ \\
Quite happy & 32 & $23.5 \%$ \\
A little happy & 41 & $30.1 \%$ \\
Neither happy nor unhappy & 16 & $11.8 \%$ \\
A little unhappy & 3 & $2.2 \%$ \\
Quite unhappy & 3 & $2.2 \%$ \\
Very unhappy & & \\
She believes that her outlook for the future is ... & 115 & $84.6 \%$ \\
Better than the present & 13 & $9.6 \%$ \\
The same as the present & 5 & $3.7 \%$ \\
Worse than the present & 5
\end{tabular}

As Table 2 shows, $53.6 \%$ of the interviewees said that in general they were happy. However, $16.2 \%$ said they felt at least a little unhappy. As regards expectations for the future, most believe that their future would be better than the present, and only $3.7 \%$ believed that their situation in the future would be worse than when the interview took place.

The relationship between the overall level of happiness and future expectations of women in poverty who are victims of IPV is shown in Table 3. 
Table 3. Differences in overall happiness according to future expectations of women in poverty who are victims of intimate partner violence in León (Nicaragua).

\begin{tabular}{|c|c|c|c|}
\hline & $\begin{array}{l}\text { Unhappy } \\
(\mathrm{n}=22)\end{array}$ & $\begin{array}{l}\text { Happy } \\
(n=73)\end{array}$ & $\chi^{2}$ \\
\hline She believes that her outlook for the future is ... & & & $18.638 * * *$ \\
\hline Better than the present & $63.6 \%(14)$ & $94.5 \%(69)$ & \\
\hline The same as the present & $9.1 \%(2)$ & $4.1 \%(3)$ & \\
\hline Worse than the present & $13.6 \%(3)$ & $1.4 \%(1)$ & \\
\hline
\end{tabular}

$* \mathrm{p} \leq .05 ; * * \mathrm{p} \leq .01 ; * * * \mathrm{p} \leq .001$

Table 3 shows that there is a direct relationship among the women interviewed between feeling happy and having positive expectations for the future, such that the women who said that they had best future expectations were those among whom a higher percentage said they were happy. There are no statistically significant differences between the women who said they were happy and those who said they were unhappy according to basic demographic characteristics such as age $(\mathrm{t}=.102, \mathrm{p}=.919)$, number of children $(\mathrm{t}=.304, \mathrm{p}=762)$ or being married or part of a de facto union $(49.5 \%)$ versus being single, separated or divorced $(50.5 \%)(\chi 2=.251, \mathrm{p}=.840)$.

There are also no statistically significant differences between women who said they were happy and those who said they were unhappy in terms of issues such as living with the assailant compared to not living with him $(\chi 2=.108, \mathrm{p}=.477)$; the duration of the relationship with the assailant prior to cohabitation $(\mathrm{t}=1.350, \mathrm{p}=180)$, the age at which they began living with the assailant ( $\mathrm{t}=.004, \mathrm{p}=.997)$, the length of time the assailant and victim continued to cohabit ( $\mathrm{t}=.174$, $\mathrm{p}=.862)$ and the duration of the abusive situation $(\mathrm{t}=.330, \mathrm{p}=.714)$. Similarly, no statistically significant differences between happy and unhappy interviewees were observed depending on the circumstances in which the first situation of abuse occurred (during courtship, in the first year of living together, during the first pregnancy or after the birth of children $)(\chi 2=3.869 ; \mathrm{p}=.424)$ or the frequency of abuse when it took place (daily, 2-3 times a week, once a fortnight) $(\chi 2=6555$, $\mathrm{p}=.088)$.

The relationship between the overall level of happiness of women in poverty who are victims of IPV and the time elapsed since the last episode of abuse is shown in Table 4.

Table 4. Relationship between overall happiness and the time elapsed since the last episode of abuse among women in poverty who are victims of intimate partner violence in León (Nicaragua).

\begin{tabular}{llll}
\hline & $\begin{array}{l}\text { Unhappy } \\
(\mathrm{n}=22)\end{array}$ & $\begin{array}{l}\text { Happy } \\
(\mathrm{n}=73)\end{array}$ & $\chi^{\mathbf{2}}$ \\
\hline $\begin{array}{l}\text { Most recent episode of abuse } \\
\text { In the last month }\end{array}$ & $47.6 \%(10)$ & $19.4 \%(14)$ & \\
Between 1 and 3 months ago & $14.3 \%(3)$ & $5.6 \%(4)$ \\
Between 3 and 6 months ago & $4.8 \%(1)$ & $5.6 \%(4)$ \\
More than 6 months ago & $23.8 \%(5)$ & $26.4 \%(19)$ \\
More than one year ago & $9.5 \%(2)$ & $43.1 \%(31)$ & \\
\hline
\end{tabular}

$* \mathrm{p} \leq .05 ; * * \mathrm{p} \leq .01 ; * * \mathrm{p} \leq .001$ 
As shown in Table 4, the time elapsed since the last episode of abuse seemed to influence the overall level of happiness expressed by women in poverty who are victims of intimate partner violence, so that a smaller percentage of the interviewees who had suffered the most recent episode of abuse during the three months prior to the interview say they are happy. Substantially higher percentages of women who had suffered from aggression more than 6 months before the interview was conducted said they were generally happy, and this was especially true among those that said that over a year had passed since the most recent assault.

Both the personal and family incomes of women in poverty who are victims of IPV appear to be related to the overall happiness reported. The percentage of happy women was lower among the interviewees with no personal income or with income of less than 25 dollars a week $(30.2 \%$ unhappy; happy $69.8 \%$ ) than among women with incomes of more than 25 dollars a week $(9.7 \%$ unhappy, happy $90.3 \%)(\chi 2=4.862, \mathrm{p}=.022)$. Similarly, a lower percentage of happy women was observed among interviewees with incomes of less than 25 dollars per week (42.9\% unhappy; $57.1 \%$ happy) than among those declaring that their incomes exceeded 25 dollars per week (14.9\% unhappy, $85.1 \%$ happy) $(\chi 2=8.658, \mathrm{p}=.005)$.

Table 5 contains information on the relationship between the overall happiness among women in poverty who are victims of IPV and filing an official complaint against their abuser.

Table 5. Relationship between overall happiness and filing an official complaint against assailants among women in poverty who are victims of intimate partner violence in León (Nicaragua).

\begin{tabular}{llll}
\hline & $\begin{array}{l}\text { Unhappy } \\
(\mathrm{n}=22)\end{array}$ & $\begin{array}{l}\text { Happy } \\
(\mathrm{n}=73)\end{array}$ & $\chi^{\mathbf{2}}$ \\
\hline Has filed a complaint against her partner & & & $18.123 * * *$ \\
No & $18.2 \%(4)$ & $42.5 \%(31)$ & \\
Yes, but it is not ongoing & -- & $9.6 \%(7)$ & \\
Yes, and it is ongoing & $40.9 \%(9)$ & $6.8 \%(5)$ & \\
Yes, but she withdrew it & $40.9 \%(9)$ & $41.1 \%(30)$ & \\
\hline
\end{tabular}

$* \mathrm{p} \leq .05 ; * * \mathrm{p} \leq .01 ; * * * \mathrm{p} \leq .001$

Table 5 shows that a higher percentage of women in poverty who are victims of IPV who had never filed a complaint against their assailant were happier than those who had filed official complaints. Furthermore, the lowest percentage of happy women was among those who had an ongoing complaint at the time of the interview, followed by those who had filed an official complaint at some point but had subsequently withdrawn it.

In terms of the social support available to the women in poverty who are victims of IPV interviewed, there were differences between the mean scores on the "Scale of Perceived Social Support" for women who said they were happy $(\mathrm{M}=29.93, \mathrm{SD}=8.86)$ and those who said they were unhappy $(\mathrm{M}=23.45, \mathrm{SD}=5.84)(\mathrm{t}=3987, \mathrm{p}=.000)$, with interviewees who said they were happy having higher mean scores on the "Scale of Perceived Social Support."

The relationship between overall happiness and various aspects related to perceived social support and satisfaction with social relations among women in poverty who are victims of IPV is shown in Table 6. 
Table 6. Relationship between overall happiness and various aspects related to social relations among women in poverty who are victims of intimate partner violence in León (Nicaragua).

\begin{tabular}{|c|c|c|c|}
\hline & $\begin{array}{l}\text { Unhappy } \\
(\mathrm{n}=22)\end{array}$ & $\begin{array}{l}\text { Happy } \\
(\mathrm{n}=73)\end{array}$ & $\chi^{2}$ \\
\hline To what extent she feels lonely or abandoned & & & $20.566 * * *$ \\
\hline Not at all & $4.5 \%(1)$ & $26.4 \%(19)$ & \\
\hline A little & $45.5 \%(10)$ & $63.9 \%(46)$ & \\
\hline Quite a lot & $22.7 \%(5)$ & $6.9 \%(5)$ & \\
\hline A lot & $27.3 \%(6)$ & $2.8 \%(2)$ & \\
\hline $\begin{array}{l}\text { She has someone she is sure she can turn to in } \\
\text { the event of difficulties or need }\end{array}$ & & & $7.790 * *$ \\
\hline Yes & $63.6 \%(14)$ & $89.0 \%(65)$ & \\
\hline No & $36.4 \%(8)$ & $11.0 \%(8)$ & \\
\hline $\begin{array}{l}\text { Level of satisfaction with her relationship } \\
\text { with her partner }\end{array}$ & & & $7.441 *$ \\
\hline None & $35.7 \%(5)$ & $15.4 \%(8)$ & \\
\hline A little & $57.1 \%(8)$ & $40.4 \%(21)$ & \\
\hline Quite a lot & $7.1 \%(1)$ & $21.2 \%(11)$ & \\
\hline A lot & --- & $23.1 \%(12)$ & \\
\hline $\begin{array}{l}\text { Level of satisfaction with her relationship } \\
\text { with her family }\end{array}$ & & & 5.800 \\
\hline Not at all & $22.7 \%(5)$ & $13.7 \%(10)$ & \\
\hline A little & $31.8 \%(7)$ & $19.2 \%(14)$ & \\
\hline Quite a lot & $40.9 \%(9)$ & $41.1 \%(30)$ & \\
\hline A lot & $4.5 \%(1)$ & $26.0 \%(19)$ & \\
\hline $\begin{array}{l}\text { Level of satisfaction with her relationship } \\
\text { with her friends }\end{array}$ & & & $9.188^{*}$ \\
\hline None & $63.6 \%(14)$ & $30.1 \%(22)$ & \\
\hline A little & $18.2 \%(4)$ & $47.9 \%(35)$ & \\
\hline Quite a lot & $13.6 \%$ & $12.3 \%(9)$ & \\
\hline A lot & $4.5 \%$ & $9.6 \%(7)$ & \\
\hline
\end{tabular}

$* \mathrm{p} \leq .05 ; * \mathrm{p} \leq .01 ; * * * \mathrm{p} \leq .001$

As can be seen in Table 6, the highest percentages of women in poverty who are victims of IPV who said they were happy were those who did not feel alone or abandoned, those who had someone to turn to if they needed support or were in need, those who felt very satisfied with their relationship with their partner and those who were a little satisfied with their relationship with their friends. No statistically significant differences between the interviewees were observed in terms of feeling happy and unhappy as regards their level of satisfaction with their relationship with their family. 


\section{Conclusions and discussion}

The overwhelming majority of the women in poverty who were victims of IPV interviewed in León (Nicaragua) are optimistic as regards the future, and more than half say that they are happy. This is despite the poverty in which they live, the stigmatization they suffer from in their social context and intensity of the stressful life events that have had to deal with (Vazquez, Panadero \& Martin, 2012), which include intimate partner violence.

Easterlin (2001) notes that even when the perception of happiness experienced remains constant, people tend to think that they were worse off in the past and that they will be much better off in the future. In this regard, women in poverty who are victims of IPV present a clear relationship between being happy and having positive future expectations. Despite having been subjected to powerful stressors, such as intimate partner violence, and living in poverty (and occasionally extreme poverty), there is a tendency for interviewees to remain optimistic regarding their future. This is especially marked among those who say they are happy. The overall feeling of happiness seems to induce optimistic cognitions, leading to better expectations for the future. Their optimistic expectations for the future may in turn positively influence their feeling of overall happiness.

Optimism is considered an inherited personality trait that predicts overall happiness by various authors (Carver \& Gains, 1987; Fontaine \& Jones, 1997; Scheier \& Carver, 1992), with a stable incidence on daily fluctuations in attitudes, emotions and behaviours (Diener \& Lucas, 1999; Weis et al. 2008). In this respect, the optimism shown by the interviewees may help explain the substantial percentage of women who are happy despite the difficult situations they are going through or have gone through.

Furthermore, different studies have stressed the existence of a positive relationship between happiness and income level (Andrews, 1986; Diener et al., 1993; Oswald, 1997), and note that the individual's personal financial situation may play an important role in accounting for happiness (Rojas, 2011). However, the significant percentage of poor women interviewed who are happy, calls into question the principles that emphasize the importance of income for happiness. The interviewees present a low (and sometimes negligible) capacity for consumption, meaning that the association between "utility" (the satisfaction obtained by a consumer when enjoying a certain amount of goods or services via consumption) and well-being reported by several studies (Rojas, 2011), is questionable.

According to Schimmel (2009), the substantial percentage of poor women who say they are happy could arise from the fact that their opportunities to meet their absolute needs are not compared with other members of their society to whose standards of living they may aspire. A lower percentage of the women interviewed with personal or family income of less than 3.5 dollars a day, who could be considered as living in extreme poverty, said that they were happy than among the women earning higher incomes, who could meet their basic needs to a greater extent and who mostly said they were happy. According to the results reported by Schimmel (2009), when the women interviewed have sufficient resources to meet their basic needs, they have a high probability of being happy. The data collected seem to reinforce the idea mentioned by Rojas (2011) that people living in poverty are more than mere consumers, and there are other important things in their lives beyond money that help them to be happy.

Overall happiness appears to be based on the satisfaction that people find in different areas of their life (Rojas, 2008), and as such the different circumstances that surround people, and which are secure and stable elements in their life, may affect the generation of feelings of happiness in 
general terms (Diener et al., 2006; Lyubomirsky, 2011; Lyubomirsky et al. 2005). In this regard, two of the circumstances that most consistently predict high overall levels of happiness are being married (Diener at al., 2000; Lee et al., 1991; Myers, 2000; Stack \& Eshelmen, 1998, Gustavson et al., 2012), and being sufficiently wealthy to meet basic needs (Diener \& Biswas-Diener, 2002; Diener et al. 1993, 1995, 2010). However, among the women in poverty who are victims of intimate partner violence, although there is a relationship between having enough resources to meet basic needs and being happy, no differences were observed in terms of their overall happiness expressed as regards living as part of a couple (married or forming stable de facto partnerships) or otherwise (single, separated or divorced). This lack of a relationship may be due to the IPV experienced, since the women interviewed who do not live with their partner would be less prone to suffering from this kind of violence, and this could affect their perception of overall happiness. However, these questions are consistent with those reported by Caunt et al. (2012), who observed that while sufficient wealth is strongly represented among the recipes for happiness, relationships within a couple, including "happy marriage", are identified as sources of happiness with moderate frequency.

In general, social relationships and stable ties with family, friends, partners, and community are good predictors of subjective well-being and overall happiness (Diener \& Seligman, 2002; Gustavson et al., 2012), and may be a factor that helps to explain the high percentage of women in poverty who are victims of IPV who say they are happy. While living with a partner does not appear to influence the overall happiness of the women interviewed, maintaining a very satisfactory relationship with a partner does seem to have positive effects on the overall happiness reported. Despite the situations of great adversity experienced by the interviewees, under very favourable conditions their relationship may therefore be an important source of social support with positive effects on their well-being and overall happiness. The influence of social support on the overall happiness of the women interviewed is also reflected in the higher percentage of happy women among the interviewees with high scores on the "Scale of Perceived Social Support", among those who said they did not feel alone or abandoned, and those who had someone to turn to in the event of difficulties or need. According to the results reported by various authors (Diener \& Oishi, 2005; Diener \& Seligman, 2002), social relationships are important for happiness, while the lack thereof, or social relations of poor quality, appear to have a negative impact on happiness (Campbell, 1981; Dolan et al., 2008).

Caunt et al. (2012) suggest that relationships with family and friends are a very important factor in individuals' well-being, and this is especially true when the family income is low (Schimmel, 2009). However, there is no clear relationship between overall happiness and satisfaction with relationships with friends among the poor women interviewed. The highest percentage of happy women is among those who say that they are not satisfied with their relationship with their friends, and the absence of a statistically significant relationship between reported overall happiness and satisfaction with their relationship with their family is especially noteworthy.

When analyzing the relationship between overall happiness and the issues surrounding IPV suffered by the interviewees, we observed that the variable that affects happiness to the greatest extent is the time elapsed since the women had suffered the most recent episode of abuse, such that the longer this period, the higher the percentage of women who say they feel happy. The women find it more difficult to be happy in general terms when they have recently suffered from an episode of abuse. However, the interviewees presented a great deal of ability to overcome difficulties, as the 
percentage of women who said that they were happy one year after the most recent episode of abuse was extremely high.

The other aspects concerning the IPV suffered by the interviewees included the lack of a relationship between feeling happy or unhappy and circumstances as relevant as cohabiting with the assailant, the length of the relationship with him prior to cohabitation, the age at which they began to live together, the amount of time the assailant and victim continued to live together, how long the abusive situation lasted, its frequency and the circumstances in which the first incidence of abuse arose. The influence of these factors on the overall happiness of the interviewees appears to diminish after a sufficient length of time has elapsed since the last episode of abuse suffered, and in this respect the women present a high level of resilience.

Finally, it is noteworthy that the highest percentage of happy women were those who had never filed an official complaint against their partner, and the lowest percentage of happy women was observed among those who maintained an ongoing complaint at the time of the interview, followed by those who at some point had filed an official complaint against their partner but had subsequently withdrawn the complaint filed. Filing a complaint, especially in the recent past or when the complaint is ongoing, seems to have a negative effect on the overall feeling of happiness, probably due to the high levels of stress that it entails for those making the complaint.

On this basis, in order to improve the wellbeing of women in poverty who are victims of IPV, it seems relevant to provide them with some degree of optimism to face the future. To this end, the people and organizations working with this population should supply them with counselling, psychological support and training in coping strategies. This would empower women with effective strategies to rely on when meeting the main challenges that they are confronted with. Simultaneously, it would be relevant to design policies specifically aimed at giving support to either women who have experienced IPV recently, or those who are currently in the process of reporting their aggressors, a circumstance that seems to create a major stress factor with a negative impact on their wellbeing.

It is undoubtedly a matter for concern that $16 \%$ of women in poverty who are victims of IPV in León (Nicaragua) state that they feel at least a little unhappy, and that $4 \%$ believe that they will feel worse in the future. However, what is really remarkable is that more than half of the women interviewed feel happy, and that $85 \%$ are convinced that they will be able to achieve a better quality of life in the future with some effort and perseverance. The ability of the women interviewed to cope with adversity, and their positive expectations for the future despite their situation are factors that provide an optimistic note as regards the opportunities for women in poverty who are victims of IPV for normalizing their circumstances and gaining access to a better quality of life.

\section{References}

Andrews, F.M. (1986). Research on the Quality of Life. Ann Harbor: Survey Research Center, Institute of Social Research, University of Michigan.

Arechabala, M.C. \& Miranda, C. (2002). Validation of a Scale of Perceived Social Support in a group of elders under control in a hypertension program in the metropolitan region. Ciencia $y$ Enfermería, 8(1),49-55.

Brannan, D., Biswas-Diener, R., Mohr, C.D., Mortazavi, S., \& Stein, N. (2013). Friends and family: A cross-cultural investigation of social support and subjective well-being among college students. The Journal of Positive Psychology, 8(1),65-75. 
Campbell, A. (1981). The Sense of Well-Being in America. New York: McGraw-Hill

Carver, C.S. \& Gains, J.G. (1987). Optimism, pessimism, and postpartum depression. Cognitive Therapy and Research, 11,449-462.

Caunt, B.S., Franklin, J., Brodaty, N.E., \& Brodaty, H. (2012). Exploring the causes of subjective well-being: A content analysis of peoples' recipes for long-term happiness. Journal of Happiness Studies. DOI 10.1007/s10902-012-9339-1.

Diener, E. \& Biswas-Diener, R. (2002). Will money increase subjective well-being?. Social Indicators Research, 57(2),119-169.

Diener, E. \& Lucas, R.E. (1999). Personality and subjective well-being. In D. Kahneman, E. Diener \& N. Schwartz (Eds.), Well-Being: The Foundations of Hedonic Psychology. New York: Russell Sage Foundation.

Diener, E. \& Oishi, S. (2005). The nonobvious social psychology of happiness. Psychological Inquiry, 16(4),162-167.

Diener, E. \& Seligman, M.E. (2002). Very happy people. Psychological Science, 13(1),81-84.

Diener, E. (1984). Subjective well-being. Psychological Bulletin, 95(3),542-575.

Diener, E., Diener, M,. \& Diener, C. (1995). Factors predicting the subjective well-being of nations. Journal of Personality and Social Psychology, 69,851-864.

Diener, E., Gohm, C.L., Suh, M., \& Oishi, S. (2000). Similarity of the relation between marital status and subjective well-being across cultures. Journal of Cross Cultural Psychology, 31,419-436.

Diener, E., Lucas, R.E., \& Scollon, C.N. (2006). Beyond the hedonic treadmill: Revising the adaptation theory of well-being. American Psychologist, 61(4),305-314.

Diener, E., Ng, W., Harter, J., \& Arora, R. (2010). Wealth and happiness across the world: Material prosperity predicts life evaluation, whereas psychosocial prosperity predicts positive feeling. Journal of Personality and Social Psychology, 99(1),52-61.

Diener, E., Sandvik, E., Seidlitz, L., \& Diener, M. (1993). The relationship between income and subjective well-being: Relative or absolute? Social Indicators Research, 28(3),195-223.

Dolan, P., Peasgood, T., \& White, M. (2008). Do we really know what makes us happy? A review of the economic literature on the factors associated with subjective well-being. Journal of Economic Psychology, 29(1),94-122.

Easterlin, R.A. (2001). Income and happiness: Towards a unified theory. The Economic Journal, 111,465-484.

Fontaine, K.R. \& Jones, L.C. (1997). Self-esteem, optimism, and post-partum depression. Journal of Clinical Psychology, 53,59-63

Graham, C. (2005). The economics of happiness. Insights on globalization form a novel approach. World Economics, 6(3),41-55.

Gustavson, K., Røysamb, E., Soest, T., Helland, M.J., \& Mathiesen, K.S. (2012). Longitudinal associations between relationship problems, divorce, and life satisfaction: Findings from a 15year population-based study. The Journal of Positive Psychology, 7(3),188-197.

Rojas, M. (2006). Well-Being and the complexity of poverty: A subjective well-being approach. In M. McGillivray \& M. Clarke (Eds.), Understanding Human Well-Being. New York: United Nations University Press.

Karma, U. \& Karma, G. (Eds.) (2004). Gross National Happiness and Development. Thimphui, Bhutan: The Centre for Bhutan Studies

Lee, G.R., Seccombe, K., \& Shehan, C,L. (1991). Marital status and personal happiness: An analysis of trend data. Journal of Marriage and the Family, 53,839-844. 
Lyubomirsky, S. (2011). Hedonic adaptation to positive and negative experiences. In S. Folkman (Ed.), The Oxford Handbook of Stress, Health and Coping. New York: Oxford University Press.

Lyubomirsky, S., King, L., \& Diener, E. (2005). The benefits of frequent positive affect: Does happiness lead to successes?. Psychological Bulletin, 131(6),803-855.

Myers, D.G. (2000). The funds, friends, and faith of happy people. American Psychologist, 55(1),56-67.

Oswald, A. (1997). Happiness and economic performance. The Economic Journal, 445(107),18151831.

Pavot, W., Diener, E., \& Fujita, F. (1990). Extraversion and happiness. Personality and Individual Differences, 11,1299-1306.

UNDP (2010). Human Development Report 2010. The Real Wealth of Nations: Pathways to Human Development. New York: United Nations Development Program.

UNDP (2011) Human Development Report 2011. Sustainability and Equity: A Better Future for All. New York: United Nations Development Program.

Rojas, M. (2008). Experienced poverty and income poverty in Mexico: A subjective well-being approach. World Development, 36(6),1078-1093.

Rojas, M. (2011). Happiness, income, and beyond. Applied Research Quality Life, 6,265-276.

Scheier, M.F. \& Carver, C.S. (1992). Effects of optimism on psychological and physical wellbeing: Theoretical overview and empirical update. Cognitive Therapy and Research, 16,201228.

Schimmel, J. (2009). Development and happiness: The subjective perception of happiness and UNDP's analysis of poverty, wealth and development. Journal of Happiness Studies, 10,93111.

Stack, S. \& Eshelmen, R. (1998). Marital status and happiness: A 17-nation study. Journal of Marriage and the Family, 60(2),527-536.

Vázquez, J.J. (2013). Happiness among the garbage. Differences in overall happiness among trash pickers in León (Nicaragua). The Journal of Positive Psychology, 8(1),1-11.

Vázquez, J.J., Panadero, S., \& Martín, R.M. (2012). Vivir de la Basura en Nicaragua. Análisis de la Situación y Necesidades de los Recolectores en el Basurero de León. Saarbrücken: Editorial Académica Española.

Veenhoven, R. (1993). Happiness in Nations, Subjetive Appreciations of Life in 56 Nations 19461992. Rotterdam: Erasmus University.

Weis, A., Bates, T.C., \& Luciano, M. (2008). On the relation between meaning in life and psychological well-being. British Journal of Psychology, 83,133-145.

Zimet, G.D., Dahlem, N.W., Zimet, S.G., \& Farley, G.K. (1988). The multidimensional scale of perceived social support. Journal of Personality Assessment, 52,30-41. 